\title{
Ductal Plate Malformation
}

National Cancer Institute

\section{Source}

National Cancer Institute. Ductal Plate Malformation. NCI Thesaurus. Code C97072.

A congenital disorder of the intrahepatic bile ducts characterized by abnormal embryonal development of the ductal plates. 